\title{
Metadata description of the ORCA database (ORganic and Conventional Agriculture's impact on aquatic biodiversity)
}

Marie Cours (D), Pieter Lemmens (1D), Rafaela Almeida, Rein Brys (D), Luc Denys (D), Aaike De Wever (D), Marc Knockaert, An Leyssen (1D), Joachim Mergeay (D), Jo Packet (1) , Koen Parmentier (1), Isa Schön (D), Jeroen Venderickx, Thierry Vercauteren, Dries Adriaens (iD, Koen Martens (i) \& Luc De Meester (i)
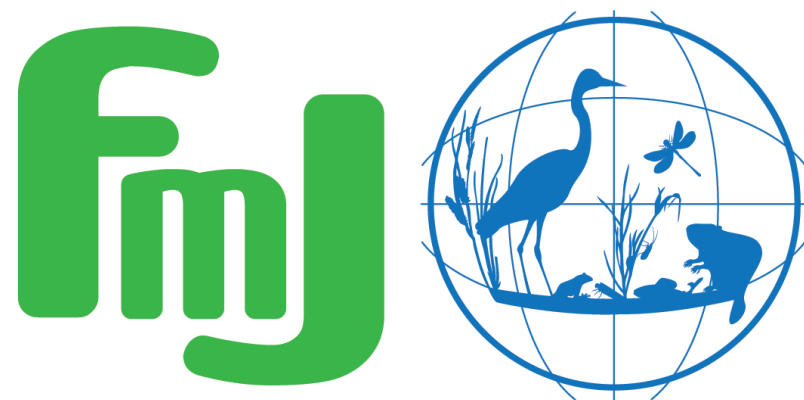

Freshwater Metadata Journal 



\title{
Metadata description of the ORCA database (ORganic and Conventional Agriculture's impact on aquatic biodiversity)
}

\author{
Marie Cours ${ }^{1}$ (D) , Pieter Lemmens ${ }^{3}$ (D), Rafaela Almeida ${ }^{3}$, Rein Brys ${ }^{2}$ (D), \\ Luc Denys ${ }^{2}$ (D), Aaike De Wever ${ }^{2}$ (D) , Marc Knockaert ${ }^{1}$, An Leyssen ${ }^{2}$ (D), \\ Joachim Mergeay ${ }^{2}$ (D), Jo Packet ${ }^{2}$ (D), Koen Parmentier ${ }^{1}$ (D), \\ Isa Schön ${ }^{1}$ (D), Jeroen Venderickx ${ }^{1}$, Thierry Vercauteren ${ }^{1}$, Dries Adriaens ${ }^{2}$ (iD), \\ Koen Martens ${ }^{1}$ (iD) \& Luc De Meester ${ }^{3}$ \\ 1 Operational Directorate Natural Environment, Royal Belgian Institute of Natural Sciences, Brussels, Belgium; corresponding author: \\ marie.cours@naturalsciences.be \\ 2 Research Institute for Nature and Forest (INBO), Brussels, Belgium \\ 3 Laboratory of Aquatic Ecology, Evolution and Conservation, KU Leuven, Leuven, Belgium
}

Please cite this paper as follows: Cours, M., Lemmens, P., Almeida, R., Brys, R., Denys, L., De Wever, A., Knockaert, M., Leyssen, A., Mergeay, J., Packet, J., Parmentier, K., Schön, I., Venderickx, J., Vercauteren, T., Adriaens, D., Martens, K. \& De Meester, L., 2021. Metadata description of the ORCA database (ORganic and Conventional Agriculture's impact on aquatic biodiversity). Freshwater Metadata Journal 52: 1-11. https://doi.org/10.15504/fmj.2021.52

Received: 2021-04-08 / Published: 2021-05-27

\section{Keywords}

farmland ponds, occurences, environmental coditions, organic agriculture, Belgium

\section{Short description of the dataset/summary}

The database of the ORCA project (A comparative analysis of ORganic and Conventional Agriculture's impact on aquatic biodiversity) comprises species occurrence data of different organism groups (zooplankton, macro-invertebrates, macrophytes, amphibians (eDNA) and fish (eDNA)) and data on physical, chemical and morphometric variables of 48 small farmland ponds distributed over Flanders, Belgium.

\section{Short description of the dataset/summary (original/national language)}

De database van het ORCA project (een vergelijkende studie naar de impact van biologische en conventionele landbouw op aquatische biodiversiteit) omvat gegevens over het voorkomen van soorten in verschillende groepen organismen (zoöplankton, macro-invertebraten, macrofyten, amfibieën (eDNA) en vissen (eDNA)) en gegevens over fysische, chemische en morfometrische variabelen van 48 kleine in het landbouwareaal gesitueerde vijvers verspreid over Vlaanderen, België. 


\section{General information}

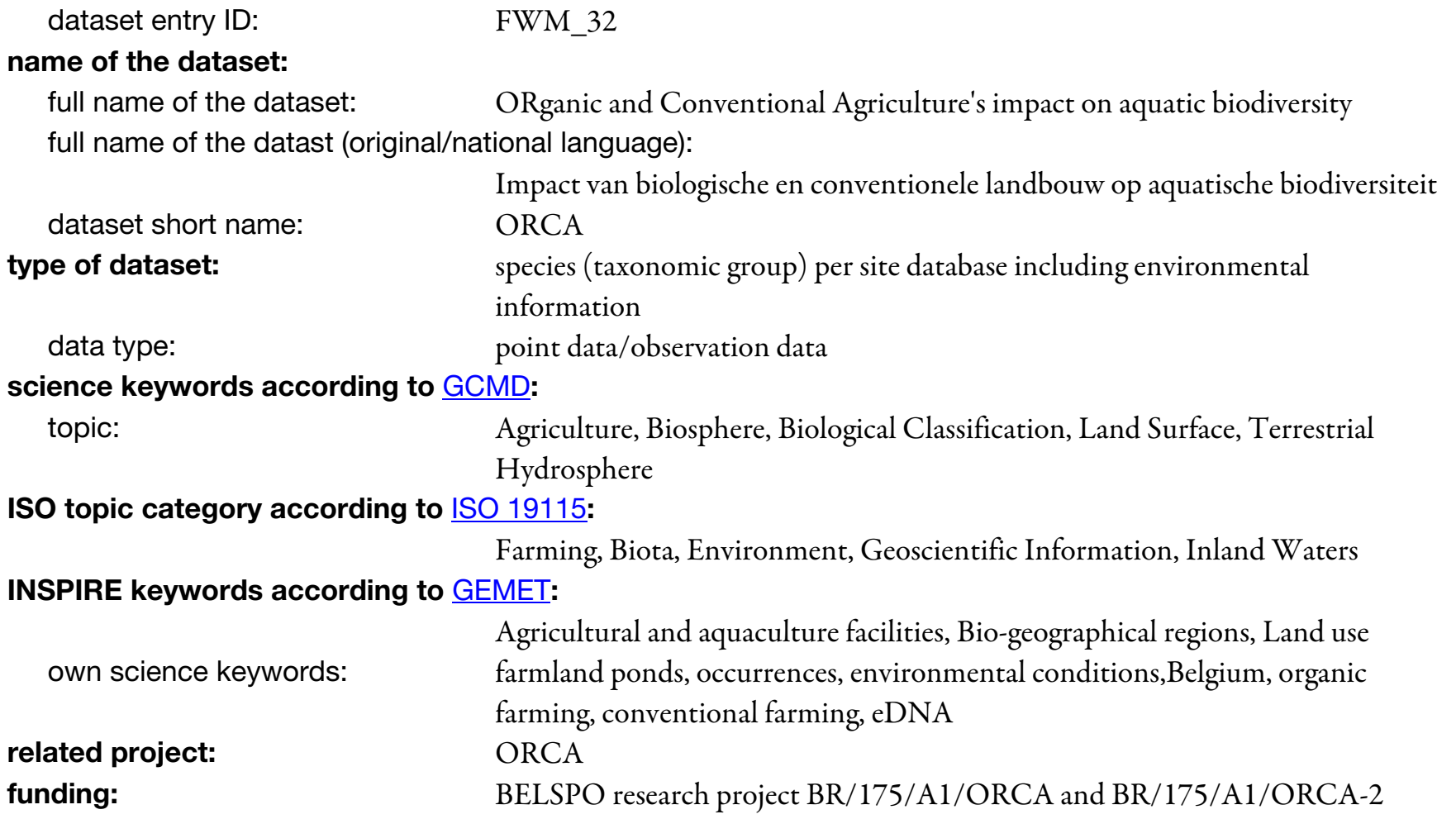

\section{Technical and administrative specifications}

$\begin{array}{ll}\text { data format: } & \text { Excel } \\ \text { operating system: } & \text { all Windows systems } \\ \text { data language: } & \text { English } \\ \text { current access level: } & \text { internal } \\ \text { currently available through GBIF: } & \text { no } \\ \text { exchange planned: } & \text { yes } \\ \text { data in data repository: } & \text { no }\end{array}$

Do you plan to publish the data on the Freshwater Biodiversity Data Portal:

$\begin{array}{ll}\text { update level: } & \text { completed } \\ \text { documentation: } & \\ \text { type: } & \text { manual } \\ \text { language: } & \text { English }\end{array}$

\section{contact details:}

metadata contact person:

$\begin{array}{ll}\text { first, last name: } & \text { Luc De Meester } \\ \text { phone: } & +3216323708 \\ \text { email: } & \text { luc.demeester@kuleuven.be } \\ \text { institution: } & \text { KU Leuven } \\ \text { address: } & \text { Charles Deberiotstraat 32 - box } 2439 \\ \text { postal code, city: } & \text { 3000 Leuven } \\ \text { country: } & \text { Belgium } \\ \text { web address: } & \underline{\text { https://bio.kuleuven.be/eeb/ldm }}\end{array}$


technical contact person:

first, last name:

Pieter Lemmens

phone:

+3216373691

email:

pieter.lemmens@kuleuven.be

scientific contact person:

first, last name:

Pieter Lemmens

phone:

+3216373691

email:

pieter.lemmens@kuleuven.be

\section{Intellectual property rights and citation}

dataset creator (data compiler):

contact name:

contact email:

Marie Cours

contact institution:

marie.cours@naturalsciences.be

Royal Belgian Institute of Natural Sciences

data contributors to/owners of this dataset:

multiple

number:

17

\section{data contributor/owner 1:}

contact name:

contact email:

luc.demeester@kuleuven.be

contact institute:

KU Leuven

criteria for using this part of the dataset:

The dataset is publicly available (data portal, data archive) and can be used without restrictions, but dataset creator/data contributors must be informed prior to publication. Data must be acknowledged and cited correctly.

data contributor/owner 2:

contact name:

contact email:

koen.martens@naturalsciences.be

contact institute:

Royal Belgian Institute of Natural Sciences

criteria for using this part of the dataset:

The dataset is publicly available (data portal, data archive) and can be used without restrictions, but dataset creator/data contributors must be informed prior to publication. Data must be acknowledged and cited correctly.

\section{data contributor/owner 3:}

contact name:

contact email:

dries.adriaens@inbo.be

contact institute:

Research Institute for Nature and Forest (INBO)

criteria for using this part of the dataset:

The dataset is publicly available (data portal, data archive) and can be used without restrictions, but dataset creator/data contributors must be informed prior to publication. Data must be acknowledged and cited correctly.

data contributor/owner 4:

contact name:

contact email:

pieter.lemmens@kuleuven.be

contact institute:

KU Leuven

criteria for using this part of the dataset:

The dataset is publicly available (data portal, data archive) and can be used without restrictions, but dataset creator/data contributors must be informed prior to publication. Data must be acknowledged and cited correctly. 


\section{data contributor/owner 5:}

contact name:

contact email:

jeroen.venderickx@naturalsciences.be

contact institute:

Royal Belgian Institute of Natural Sciences

criteria for using this part of the dataset:

The dataset is publicly available (data portal, data archive) and can be used without restrictions, but dataset creator/data contributors must be informed

data contributor/owner 6: prior to publication. Data must be acknowledged and cited correctly.

contact name:

contact email:

luc.denys@inbo.be

contact institute:

Research Institute for Nature and Forest

criteria for using this part of the dataset:

The dataset is publicly available (data portal, data archive) and can be used without restrictions, but dataset creator/data contributors must be informed prior to publication. Data must be acknowledged and cited correctly.

\section{data contributor/owner 7:}

contact name:

contact email:

contact institute:

rafaela.almeida@kuleuven.be

criteria for using this part of the dataset:

The dataset is publicly available (data portal, data archive) and can be used without restrictions, but dataset creator/data contributors must be informed prior to publication. Data must be acknowledged and cited correctly.

data contributor/owner 8:

contact name:

contact email:_ marie.cours@naturalsciences.be

contact institute: Royal Belgian Institute of Natural Sciences

criteria for using this part of the dataset:

The dataset is publicly available (data portal, data archive) and can be used without restrictions, but dataset creator/data contributors must be informed prior to publication. Data must be acknowledged and cited correctly.

data contributor/owner 9:

contact name:

contact email:

rein.brys@inbo.be

contact institute:

Research Institute for Nature and Forest

criteria for using this part of the dataset:

The dataset is publicly available (data portal, data archive) and can be used without restrictions, but dataset creator/data contributors must be informed

data contributor/owner 10: prior to publication. Data must be acknowledged and cited correctly.

contact name:

contact email:

contact institute:

jo.packet@inbo.be

criteria for using this part of the dataset:

The dataset is publicly available (data portal, data archive) and can be used without restrictions, but dataset creator/data contributors must be informed prior to publication. Data must be acknowledged and cited correctly.

data contributor/owner 11:

contact name: 
contact email: contact institute: criteria for using this part of the dataset:

joachim.mergeay@inbo.be

Research Institute for Nature and Forest

The dataset is publicly available (data portal, data archive) and can be used without restrictions, but dataset creator/data contributors must be informed prior to publication. Data must be acknowledged and cited correctly.

data contributor/owner 12:

contact name:

contact email:

marc.knockaert@naturalsciences.be

contact institute:

Royal Belgian Institute of Natural Sciences

criteria for using this part of the dataset:

The dataset is publicly available (data portal, data archive) and can be used without restrictions, but dataset creator/data contributors must be informed prior to publication. Data must be acknowledged and cited correctly.

data contributor/owner 13:

contact name:

contact email: $\quad$ koen.parmentier@naturalsciences.be

contact institute:

Royal Belgian Institute of Natural Sciences

criteria for using this part of the dataset:

The dataset is publicly available (data portal, data archive) and can be used without restrictions, but dataset creator/data contributors must be informed prior to publication. Data must be acknowledged and cited correctly.

data contributor/owner 14:

contact name:

contact email:

contact institute:

aaike.dewever@inbo.be

criteria for using this part of the dataset:

The dataset is publicly available (data portal, data archive) and can be used without restrictions, but dataset creator/data contributors must be informed prior to publication. Data must be acknowledged and cited correctly.

data contributor/owner 15:

contact name:

contact email: an.leyssen@inbo.be

contact institute: $\quad$ Research Institute for Nature and Forest

criteria for using this part of the dataset:

The dataset is publicly available (data portal, data archive) and can be used without restrictions, but dataset creator/data contributors must be informed prior to publication. Data must be acknowledged and cited correctly.

data contributor/owner 16:

contact name:

contact email:

ischoen@naturalsciences.be

contact institute:

Royal Belgian Institute of Natural Sciences

criteria for using this part of the dataset:

The dataset is publicly available (data portal, data archive) and can be used without restrictions, but dataset creator/data contributors must be informed prior to publication. Data must be acknowledged and cited correctly.

\section{data contributor/owner 17:}

contact name:

contact email:

contact institute:

thierry.vercauteren@proximus.be

Royal Belgian Institute of Natural Sciences 
criteria for using this part of the dataset:

The dataset is publicly available (data portal, data archive) and can be used without restrictions, but dataset creator/data contributors must be informed

citation of this dataset:

author(s):

title and journal (name, number, pages):

prior to publication. Data must be acknowledged and cited correctly.

Cours, M., Lemmens, P., Almeida, R., Brys, R., Denys, L., De Wever, A.,

Knockaert, M., Leyssen, A., Mergeay, J., Packet, J., Parmentier, K., Schön, I.,

Venderickx, J., Vercauteren, T., Adriaens, D., Martens, K. \& De Meester, L.

Database of the ORCA project (A comparative analysis of ORganic and

Conventional Agriculture's impact on aquatic biodiversity).

year:

2021

\section{citation of the metadata:}

author(s):

title and journal (name, number, pages):

year: 2021

doi: $\quad$ https://doi.org/10.15504/fmj.2021.52
Metadata description of the ORCA database (ORganic and Conventional

Agriculture's impact on aquatic biodiversity). Freshwater Metadata Journal 52:

1-11

Cours M., Lemmens P., Almeida R., Brys R., Denys L., De Wever A., Knockaert M., Leyssen A., Mergeay J., Packet J., Parmentier K., Schön I., Venderickx J., Vercauteren T., Adriaens D., Martens K. \& De Meester L.

\section{General data specifications}

\section{regional coverage of the dataset:}

spatial extent of the dataset:

continents:

spatial extent (bounding coordinates):

$\begin{array}{ll}\text { southernmost latitude }\left[^{\circ}\right]: & 50.721357 \\ \text { northernmost latitude }\left[^{\circ}\right] & 51.425765 \\ \text { westernmost longitude }\left[^{\circ}\right]: & 2.645698 \\ \text { easternmost longitude }\left[^{\circ}\right]: & 5.856698 \\ \text { countries: } & \text { Europe: Belgium }\end{array}$

world climatic regions according to Köppen:

Group C: temperate/mesothermal climates

freshwater ecoregions of the world (FEOW) according to WWF:

European ecoregions according to Illies (WFD):

Europe: Central \& Western Europe

\section{ecosystem type:}

covered timeframe:
Western Plains (ER13)

lakes/ponds

$2017-2018$

\section{Site specifications}

coordinate system/grid data:

datum (e.g. WGS84):

grid data available:

site coding available: latitude/longitude, format: DD

WGS84

no

yes, alphanumerical 
example:

number of sites:

exact number of sites:

comments:

\section{WVLPOP0713}

$<100$

48

Reference:

Leyssen, A., Scheers, K., Smeekens, V., Wils, C., Packet, J., De Knijf, G. \& Denys, L. (2020). Watervlakken versie 1.1: polygonenkaart van stilstaand water in Vlaanderen. Uitgave 2020. Rapporten van het Instituut voor Natuur- en Bosonderzoek 2020 (40). Instituut voor Natuur-en Bosonderzoek, Brussel. DOI: doi.org/10.21436/inbor.19088385

http://www.geopunt.be/catalogus/datasetfolder/61c4245b-a177-4fe8-a5cc-455 $475 \mathrm{~d} 7 \mathrm{~b} 40 \mathrm{f}$

\section{Climate and environmental data}

climate related data: environmental data:

available parameters per site:

comments:

physico-chemical data: other physico-chemical parameters:

phycocyanine, DOC, Silicate, phosphate

availability of physico-chemical data, if there is more than one sample per site: mean values per site

stressors influencing the sites:

reference sites available:

\section{mean values per site}

no no climate data available

no environmental data per catchment available

maximum depth

data source: field measurement

proportion of land use types within several fixed perimeters around ponds data source: Poelmans, L. \& Van Daele, T. (2014). Landgebruikskaart NARA-T 2014: Studie uitge distance statistics between pond, buffer area and nearest crop/grassland land use reference:

Departement Landbouw \& Visserij (2016). Landbouwgebruikspercelen ALV, 2016. Verdeeld door Agentschap Informatie Vlaanderen, http://www.geopunt.be/catalogus/datasetfolder/68621fdf-7948-48eb-b141-3f8 $5751 \mathrm{c} 44 \mathrm{cb}$ total $\mathrm{P}$, nitrate, nitrite, total $\mathrm{N}$, ammonium, sulphate, chloride, hardness, alkalinity, oxygen content, water temperature, $\mathrm{pH}$, conductivity, chlorophyll, Secci disc depth, suspended solids, sediment/soil parameters 
Cours, Lemmens, Almeida, Brys, Denys, et al.

\begin{tabular}{|l|l|l|l|l|}
\hline stressor & $\begin{array}{l}\text { restored sites } \\
\text { available }\end{array}$ & $\begin{array}{l}\text { data before/after } \\
\text { restoration } \\
\text { available }\end{array}$ & $\begin{array}{l}\text { stressor gradient } \\
\text { available }\end{array}$ & comments \\
\hline other stressors & no & no & no & $\begin{array}{l}\text { organic vs conventional agricultural } \\
\text { land use }\end{array}$ \\
\hline
\end{tabular}

\title{
Biological data
}

biological data origin: from sampling,

ORCA

organism group addressed: $\quad$ amphibians, fish, macro-invertebrates (Mollusca, Coleoptera), zooplankton (Cladocera), macrophytes

comments: Three macroinvertebrate groups were addressed: Coleoptera, Heteroptera, Gastropoda.

\section{Sample specifications/sample resolution}

\author{
amphibians: \\ sample information: \\ covered timeframe: $\quad 2018-2018$ \\ historical data: no \\ season: $\quad$ spring \\ temporal resolution/frequency of sampling: \\ per year \\ time series data: \\ taxonomic resolution: \\ level: $\quad$ genus, species \\ percentage of species level data: 90 \\ taxonomic coding:
}

taxalist according to: $\quad$ INBO reference database and De Bie et al. (2012)

reference(s): $\quad$ De Bie, T., De Meester, L., Brendonck, L., Martens, K., Goddeeris, B., Ercken, D., Hampel, H., Denys, L., Vanhecke, L., Van der Gucht, K., Van Wichelen, J., Vyverman, W. \& Declerck, S.A. (2012). Body size and dispersal mode as key traits determining metacommunity structure of aquatic organisms. Ecology Letters 15(7): 740-747.

sample specifications:

type: presence/absence

replicate samples: no

number of samples: $\quad 48$

specification of method(s) used for sampling and sorting:

eDNA data

fish:

sample information:

covered timeframe:

$2018-2018$

historical data: no

palaeo data: no

season: spring

temporal resolution/frequency of sampling: 
time series data:

\section{taxonomic resolution:}

level:

percentage of species level data: 100

\section{taxonomic coding:}

taxalist according to:

reference(s): per year

no

species

INBO reference database and De Bie et al. (2012)

De Bie, T., De Meester, L., Brendonck, L., Martens, K., Goddeeris, B., Ercken, D., Hampel, H., Denys, L., Vanhecke, L., Van der Gucht, K., Van Wichelen, J., Vyverman, W. \& Declerck, S.A. (2012). Body size and dispersal mode as key traits determining metacommunity structure of aquatic organisms. Ecology Letters 15(7): 740-747.

\section{sample specifications:}

type:

presence/absence

replicate samples:

no

number of samples:

48

specification of method(s) used for sampling and sorting:

eDNA data

\section{macro-invertebrates: \\ sample information:}

covered timeframe:

$2017-2017$

historical data:

no

palaeo data:

no

season:

summer

temporal resolution/frequency of sampling:

time series data:

per year

comments:

no

\section{taxonomic resolution:}

level:

data of Coleoptera, Heteroptera and Gastropoda

percentage of species level data: 90

\section{taxonomic coding:}

taxalist according to:

reference(s):

see De Bie et al. (2012)

De Bie, T., De Meester, L., Brendonck, L., Martens, K., Goddeeris, B., Ercken, D., Hampel, H., Denys, L., Vanhecke, L., Van der Gucht, K., Van Wichelen, J., Vyverman, W. \& Declerck, S.A. (2012). Body size and dispersal mode as key traits determining metacommunity structure of aquatic organisms. Ecology Letters 15(7): 740-747.

\section{sample specifications:}

type:

semi-quantitative

replicate samples:

no

number of samples:

48

specification of method(s) used for sampling and sorting:

\section{zooplankton:}

net sampling

\section{sample information:}

covered timeframe:

$2017-2017$

historical data:

no

palaeo data:

no

season: 
temporal resolution/frequency of sampling:

time series data:

per year

taxonomic resolution:

level: $\quad$ species

percentage of species level data: 95

taxonomic coding:

taxalist according to:

reference(s):

see De Bie et al. (2012)

De Bie, T., De Meester, L., Brendonck, L., Martens, K., Goddeeris, B., Ercken, D., Hampel, H., Denys, L., Vanhecke, L., Van der Gucht, K., Van Wichelen, J., Vyverman, W. \& Declerck, S.A. (2012). Body size and dispersal mode as key traits determining metacommunity structure of aquatic organisms. Ecology Letters 15(7): 740-747.

sample specifications:

type: semi-quantitative

replicate samples: no

number of samples: $\quad 48$

specification of method(s) used for sampling and sorting:

macrophytes:

densities (number of individuals per liter)

\section{sample information:}

covered timeframe:

$2017-2018$

historical data:

no

palaeo data:

no

season:

summer

temporal resolution/frequency of sampling:

time series data: $\quad$ no

comments: $\quad 47$ samples in 2017

1 sample in 2018

taxonomic resolution:

level: $\quad$ genus, species

percentage of species level data: 95

\section{taxonomic coding:}

taxalist according to:

reference(s):

see De Bie et al. (2012)

De Bie, T., De Meester, L., Brendonck, L., Martens, K., Goddeeris, B., Ercken, D., Hampel, H., Denys, L., Vanhecke, L., Van der Gucht, K., Van Wichelen, J., Vyverman, W. \& Declerck, S.A. (2012). Body size and dispersal mode as key traits determining metacommunity structure of aquatic organisms. Ecology Letters 15(7): 740-747.

sample specifications:

type:

semi-quantitative

replicate samples:

no

number of samples:

48

specification of method(s) used for sampling and sorting:

estimated using Tansley scale 


\section{Other specifications}

GIS layers, shape files related to the dataset:

$\begin{array}{ll} & \text { land use } \\ \text { availability of photos: } & \text { yes } \\ \text { availability of maps: } & \text { no }\end{array}$

quality control procedures:

Were any quality control procedures applied to your dataset?

yes

quality control protocols and comments:

Species, difficult to identify, were checked by taxonomic experts.

\section{Acknowledgements}

The authors acknowledge the Belgian Science Policy (BELSPO) for funding the original BRAIN project ORCA (A comparative analysis of ORganic and Conventional Agriculture's impact on aquatic biodiversity - 2017-2021), as well as for funding the SAFRED project (Saving freshwater biodiversity research data - 2015-2018) that facilitated access to previous databases. We thank the pond owners for granting us access to their land and the ORCA Follow-up Committee for their much appreciated input.

\section{References}

De Bie, T., De Meester, L., Brendonck, L., Martens, K., Goddeeris, B., Ercken, D., Hampel, H., Denys, L., Vanhecke, L., Van der Gucht, K., Van Wichelen, J., Vyverman, W. \& Declerck, S.A., 2012. Body size and dispersal mode as key traits determining metacommunity structure of aquatic organisms. Ecology Letters 15(7): 740-747.

https://doi.org/10.1111/j.1461-0248.2012.01794.x

Departement Landbouw \& Visserij, 2016. Landbouwgebruikspercelen ALV, 2016. Verdeeld door Agentschap Informatie Vlaanderen.

https://doi.org/https://www.geopunt.be/catalogus/datasetfolder/68621fdf-7948-48eb-b141-3f85751c44cb

Leyssen, A., Scheers, K., Smeekens, V., Wils, C., Packet, J., De Knijf, G. \& Denys, L., 2020. Watervlakken versie 1.1: polygonenkaart van stilstaand water in Vlaanderen: uitgave 2020. Rapporten van het Instituut voor Natuur- en Bosonderzoek 2020 (nr. 40, pg 19). Instituut voor Natuur- en Bosonderzoek, Brussel. https://doi.org/10.21436/inbor.19088385

Poelmans, L. \& Van Daele, T., 2014. Landgebruikskaart NARA-T 2014: Studie uitgevoerd in opdracht van: INBO (in het kader van de Referentietaak Natuurrapportering Vlaanderen) - 2014/RMA / R /45 (55pg) https://doi.org/https://www.vlaanderen.be/inbo/publicaties/landgebruikskaart-nara-t-2014 